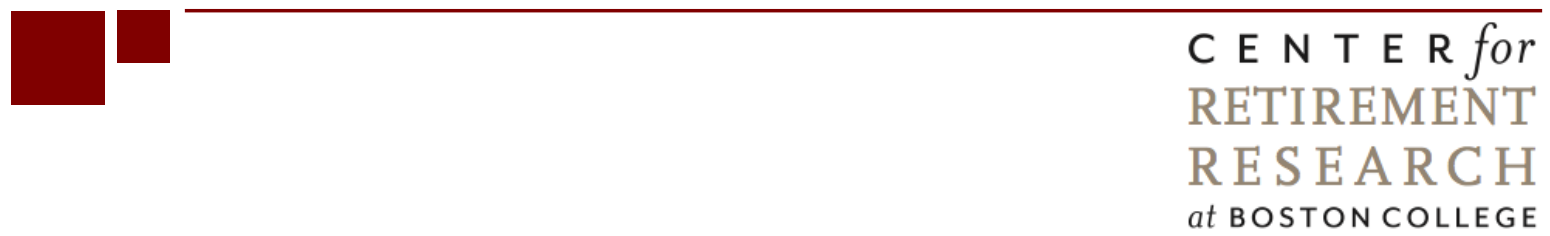

\title{
HOW DO THE DISABLED COPE WHILE WAITING FOR SSDI?
}

\author{
Norma B. Coe, Stephan Lindner, Kendrew Wong, and April Yanyuan Wu
}

CRR WP 2013-12

Submitted: May 2013

Released: June 2013

\author{
Center for Retirement Research at Boston College \\ Hovey House \\ 140 Commonwealth Avenue \\ Chestnut Hill, MA 02467 \\ Tel: 617-552-1762 Fax: 617-552-0191 \\ http://crr.bc.edu
}

Norma B. Coe is an assistant professor at the University of Washington. Stephan Lindner is a research associate at the Urban Institute. Kendrew Wong is a research associate at the Center for Retirement Research at Boston College (CRR). April Yanyuan Wu is a research economist at the CRR. The research reported herein was pursuant to a grant from the U.S. Social Security Administration (SSA), funded as part of the Retirement Research Consortium (RRC). The findings and conclusions expressed are solely those of the authors and do not represent the views of SSA, any agency of the federal government, the RRC, the University of Washington, the Urban Institute, or Boston College. All errors are their own.

(C) 2013, Norma B. Coe, Stephan Lindner, Kendrew Wong, and April Yanyuan Wu. All rights reserved. Short sections of text, not to exceed two paragraphs, may be quoted without explicit permission provided that full credit, including $(C)$ notice, is given to the source. 


\begin{abstract}
About the Center for Retirement Research
The Center for Retirement Research at Boston College, part of a consortium that includes parallel centers at the University of Michigan and the National Bureau of Economic Research, was established in 1998 through a grant from the Social Security Administration. The Center's mission is to produce first-class research and forge a strong link between the academic community and decision-makers in the public and private sectors around an issue of critical importance to the nation's future. To achieve this mission, the Center sponsors a wide variety of research projects, transmits new findings to a broad audience, trains new scholars, and broadens access to valuable data sources.
\end{abstract}

\author{
Center for Retirement Research at Boston College \\ Hovey House \\ 140 Commonwealth Avenue \\ Chestnut Hill, MA 02467 \\ phone: 617-552-1762 fax: 617-552-0191 \\ e-mail: crr@bc.edu \\ crr.bc.edu
}

Affiliated Institutions:

The Brookings Institution

Massachusetts Institute of Technology

Syracuse University

The Urban Institute 


\begin{abstract}
The wait time for a Social Security Disability Insurance (SSDI) award varies from a few months to a several years. Little is known about how applicants fund their consumption during this waiting time, while they receive no income support or medical benefits from the SSDI program. Using the Survey of Income and Program Participation (SIPP) linked to the Social Security Administration's 831 file, this paper is the first to identify the causal effect of a longer waiting time on the use of these coping strategies using an instrumental variable (IV) approach. We find that applicants react to a longer waiting time by using benefits from the Supplemental Nutrition Assistance Program (SNAP) more frequently. They are also less likely to change their address and to receive Unemployment Insurance (UI) benefits. Moreover, when comparing IV to OLS, our results also indicate that while applicants' spouses do not increase their employment due to an exogenous increase in the waiting time, an increase in their employment leads to a longer waiting time for applicants, presumably because applicants with a working spouse are more likely to appeal an initial denial. Together, these results suggest that coping strategies both help applicants to cope with the waiting time and to extend the waiting time to increase their chances of getting into the program.
\end{abstract}




\section{Introduction}

A disabled worker seeking Social Security Disability Insurance (SSDI) benefits must first undergo a multi-layered and potentially lengthy disability determination process. Approximately one-third of SSDI applicants are awarded benefits during the first stage of the application process, with an average processing time of 4.3 months; for those few who appeal all the way through to the deferral courts, the average processing time is 57 months (Autor and Duggan 2010). During the application and appeals processes, SSDI applicants receive no income support or medical benefits from the SSDI program. However, they face strong incentives to remain out of the labor force because evidence of gainful employment would disqualify their application. ${ }^{1}$

While considerable attention has been paid to how applicants fill the health insurance coverage gap, much less is known about how disabled individuals fund their consumption during the application process. Two notable exceptions include Bound, Burkhauser, and Nichols (2003) and Honeycutt (2004). They find that income from government transfers and temporary disability insurance programs partially offset the decline in SSDI applicants’ own labor earnings. However, while the wait time for SSDI has drawn increased attention from research and the policy-making arenas, the relationship between waiting time and how individuals fund consumption remains unexplored.

Using the 1990 to 2008 Survey of Income and Program Participation (SIPP) linked to the SSA's 831 file, this paper is the first to examine the causal relationship between the waiting time and various coping strategies of applicants for SSDI. Our analysis starts with documenting the evolution of applicants’ income and sources of income, before SSDI application, during application, and after the final SSDI determination. The study focuses on five types of coping strategies that applicants may rely on, including: (1) government transfers: Supplemental Nutrition Assistance Program (SNAP); Workers’ Compensation; and Unemployment Insurance (UI), ${ }^{2}$ (2) earnings of the spouse, (3) changing living arrangements, (4) borrowing from credit, and (5) liquidation of housing assets. ${ }^{3}$

\footnotetext{
${ }^{1}$ Gainful employment is defined here as earning over the Substantial Gainful Activity (SGA) amount, or more than $\$ 1,010(\$ 1,690)$ a month for non-blind (blind) disability beneficiaries in 2012.

${ }^{2}$ Supplementary Security Income program cannot be considered as a coping strategy during the application determination process because SSI applications are processed like DI applications. Temporary Disability Insurance is also excluded from the analysis because there is no information from the SIPP on receiving TDI benefits.

${ }^{3}$ We also considered receiving financial assistance from family and friends, and withdrawals from savings or 401(k) accounts as coping strategies, but fewer than $2(0.5)$ percent of the sample reported these types of income and thus are not a focus of this study.
} 
We then examine how wait time is associated with the use of each coping strategy in the initial month of application and the average use of each coping strategy over the duration of the application. We also investigate how the use of each coping strategy changes with time since application, controlling for the overall application duration. While this estimation strategy addresses some endogeneity concerns, any relationship between the time since application and the increased or decreased use of a coping strategy could be due to applicants reacting to a longer waiting time or due to some applicants using the coping strategy to fund a longer waiting time by appealing an initial denial. To separate these two effects, we employ an Instrumental Variables (IV) approach, using average waiting by state-year-stage to instrument for the actual waiting time, to identify the effect of an exogenous increase in the waiting time on the use of each coping strategy. $^{4}$

The findings can be summarized as follows. First, while the relationship between the wait time and the use of any particular coping strategy, during the initial month or on average over the spell, is largely absent, we find that applicants with an exogenously longer waiting durations are more likely to use SNAP benefits both initially and on average, and less likely to change one's address over the duration of the application. Moreover, an increase in the waiting time reduces the probability that applicants receive UI benefits, likely because these benefits cease after several months. Finally, we find a positive relationship between the time since application and spousal employment in the reduced form but no such relationship for our IV regressions. Together, these results suggests that applicants' spouses do not react to an exogenous increase in the waiting time by working more, but that a working spouse makes it more likely that applicants extend the waiting time by appealing an initial denial.

The paper proceeds as follows. Section 2 briefly outlines SSDI and reviews the existing literature. Section 3 describes the data and sample construction and presents descriptive statistics. Section 4 provides an overview of coping strategies and the determination of eligibility and take-up for each strategy. Section 5 describes how the wait time is correlated with demographic characteristics, coping strategies used at the time of application and over time as application progresses. Section 6 discusses the econometric approach and section 7 summarizes the main results, followed by concluding remarks in Section 8.

\footnotetext{
${ }^{4}$ Stage refers to the initial determination stage. We discuss this further in section 6 .
} 


\section{Background}

Social Security Disability Insurance. SSDI is a social insurance program that provides cash benefits to workers who face a work-limiting disability expected to last at least 12 months. Individuals must have worked long enough and recently enough to be SSDI-insured; that is, one must have worked an age-specific number of quarters and have worked 20 quarters in the last 10 years. $^{5}$ SSDI-insured individuals are eligible for SSDI benefits if they are not currently earning more than the Substantial Gainful Activity (SGA) level due to a disability and are expected to be unable to do so for at least a year. SSDI benefits are a function of an individual's past labor earnings, using the same formula as Social Security retirement benefits, without an actuarial adjustment for early receipt of benefits. Disabled individuals who do not medically recover will get their full Social Security retirement benefit in perpetuity, as if they had retired at their Full Retirement Age. ${ }^{6}$

SSDI Application Process. The SSA field office screens out applicants who are currently gainfully employed, that is, earning more than the SGA amount. Applications screened out at this level are labeled "technical denials," do not receive a medical review, and are not observed in our data. Applications are then sent to a state Disability Determination Service (DDS) center, where cases are assigned to disability examiners for review on a rotational basis. ${ }^{7}$ Disability examiners conduct a medical review, approving only about one-third of the cases. Applicants denied benefits at this point can appeal, first to the same DDS center that made the original determination, then to an Administrative Law Judge (ALJ). Notably, ALJs overturn SSA's initial rejections in approximately 75 percent of the cases they hear, but there is substantial variation across ALJs in the award rate (French and Song 2009). Rejected applicants can then appeal to the central Appeals Board of Washington and finally to a federal court. Because of the relatively low initial allowance rate and these lengthy appeals processes, the mean determination time for allowed applicants significantly exceeds that of denied applicants (Autor et al. 2011).

\footnotetext{
${ }^{5}$ In order to be covered by SSDI, one must have worked a minimum of 40 or (age-21) quarters overall and have earned half the credits in the last five years or since turning 21. While the rules always refer to "covered quarters," it has been a misnomer since 1978. Covered quarters are calculated by the amount one makes in a calendar year, not the amount of time one was employed. In 2012, earnings of $\$ 1,130$ are required to earn one quarter of coverage. ${ }^{6}$ Individuals may be terminated from the disability program due to medical recovery or by earnings that exceed the SGA under certain conditions. "Medical recovery" is determined through continuing disability reviews (CDRs), whose use has varied widely over time. Stapleton et al. (2010) find that only 4 percent of 1996 SSDI awardees had their benefits terminated for work in the first ten years in the program. Coe and Rupp (2013) find that approximately 1 percent of SSDI beneficiaries leave the rolls per year either due to work effort or medical recovery. ${ }^{7}$ Exceptions to rotational assignment include high-priority cases flagged as potential terminal illness cases.
} 
Hence, both for those ultimately awarded and denied benefits, the many stages of adjudication mean that the application for SSDI benefits can potentially take years.

Even if two applicants are identical in their application/appeals process, the wait time for a SSDI award also can vary substantially depending on where the disabled individuals live. Applicants living in Alabama, Illinois, Indiana, Michigan, Minnesota, Missouri, Nebraska, Ohio, Wisconsin and the District of Columbia face the longest delays; Connecticut, Delaware, Hawaii, Maine, Louisiana, Massachusetts, Oklahoma, Texas, Utah and West Virginia residents face the shortest (Allsup Study 2010). For example, an applicant who resides in Delaware will wait on average fewer than 10 months for a hearing before the ALJ, while the same applicant in Ohio would wait almost 20 months.

Further, the wait time depends on the disabling condition. For applicants who have severely disabling disorders (i.e., cancers), the Social Security Administration (SSA) is able to render a decision rapidly under its Compassionate Allowance program. By contrast, those who are suffering from subjective or difficult-to-verify disorders, such as mental illness, back pain, and soft tissue pain, are most likely to be decided on appeal.

There have been recent interventions on the part of the SSA to address the growing time lag between application and decision (for example, nationwide usage of the Quick Disability Determination (QDD) process, creation of additional ALJ positions and National Hearing Centers, and the use of video conferencing). Twenty-four of the 46 states with hearing offices saw a reduction in wait times in 2010 compared with 2008. The SSA reports that the national average processing time for a hearing decision in 2010 was 442 days, down from 514 days in September 2008 (Social Security Administration 2010). The total hearings backlog has decreased by more than 71,000 cases since December 2008 (Allsup Study 2010).

During the applications and appeals process, applicants receive no income support or medical benefits from the SSDI program. Moreover, as long as their application remains pending, they face strong incentives against participating in the labor force - even on a trial basis - since evidence of gainful employment would disqualify their claim. If an individual is allowed onto the disability benefit rolls, benefits commence five months after disability onset. Beneficiaries are eligible for Medicare 29 months after disability onset. Both cash benefits and Medicare coverage can be retroactive. 
Literature Review. Recent work on the duration of SSDI applications has estimated the causal effects on applicants' subsequent employment. Specifically, Autor et al. (2011) find that the SSDI determination process directly reduces the post-application employment of denied applicants by approximately 3.6 percentage points ( 7 percent) and allowed applicants by approximately 5.2 percentage points (33 percent). Considerable attention has also been paid to how applicants fill the health insurance coverage gap during the 29-month waiting period for Medicare benefits (for example, Gruber and Kubik 2002; Dale and Verdier 2003; Riley 2006; Livermore, Stapleton, and Claypool 2009). The evidence suggests that SSDI applicants have lower health insurance coverage rates for up to three years before application, and one-quarter of SSDI beneficiaries go uninsured during the waiting period.

However, little is known about what these disabled individuals live on before receiving SSDI benefits. Notable exceptions are Honeycutt (2004) and Bound, Burkhauser, and Nichols (2003). Honeycutt (2004) examines income from three sources: disability income, public assistance, and income related to labor force involvement in the last year before application among new SSDI beneficiaries. He finds that a large proportion of new SSDI beneficiaries receive workers compensation, employer disability, retirement income, and food stamps before obtaining SSDI benefits. Bound, Burkhauser, and Nichols (2003) further our understanding by looking not just at beneficiaries but all SSDI applicants. Using an unbalanced panel, they examine income sources three years before, at SSDI application, and three years after application, instead of just focusing on the year before benefit receipt. They find that earnings, and to a lesser extent total household income, drop dramatically six months prior to SSDI application, but rebound during the subsequent three-year period. In the early months following SSDI application, a patchwork of temporary disability benefits offset declines in SSDI applicants' own labor earnings. In the long run, most of these temporary sources of income decline and are replaced by SSDI benefits for successful applicants or earnings for denied applicants.

Although these studies shed light on how people might use other income sources as a coping strategy, it is unclear whether applicants for SSDI more and more rely on other coping strategies as they experience a longer waiting time, or whether they use other income sources to extend their waiting time, primarily be filing an appeal. The main contribution of this study to this literature is to compare both ordinary least squares (OLS) and IV estimates to parse out the 
causal relationship between various coping strategies and the waiting time. Moreover, we use more recent data and expand the list of coping strategies studied that may be available to applicants.

\section{Data, Sample, and Descriptive Statistics}

Data. This study uses data from the SSA's 831 file linked to household information from SIPP panels starting in 1990-2008. The SIPP is a nationally-representative longitudinal survey of households conducted by the U.S. Census Bureau. The main objective of the SIPP is to provide comprehensive information about income and program participation of individuals and households in the United States. Every four months over a two- to four-year period, respondents are asked a battery of questions on their labor market participation, sources of income, employment relationships, demographics and family structure, health insurance status, wealth, and public program participation during each month between interviews. New panels began annually between 1990 and 1993, plus 1996, 2001, 2004, and 2008. The SIPP panel is a useful data set for measuring changes in short term economic well-being.

The SSA's 831 file is the official disability determination data used by the Disability Determination Services. When a person applies for SSDI or Supplemental Security Income (SSI), an 831 file is opened. We use 831 records to identify the date of the first application and the type of application (SSDI vs SSI). The 831 record subsequently tracks the application through the initial determination and up to reconsideration level. ${ }^{8}$ To improve the accuracy of application outcomes, 831 files are augmented with the Master Beneficiary Records (MBR) and the Payment History Update System (PHUS). MBR and PHUS records contain complete application and determination information, and are matched to 831 files using application and benefit begin dates, respectively.

The matched data have the advantage of administrative information on SSDI application and receipt that is more accurate than self-reports, plus household and individual characteristics that are not usually available in administrative records. The long time span of the data allows us to examine changes over time.

\footnotetext{
${ }^{8}$ In a few cases, the 831 files contain the information on the level of application stage that goes beyond the ALJ level. However, the quality of the data concerning these higher-level appeals decisions is questionable.
} 
Sample. The sample for this analysis includes individuals who are matched to Social Security data (they either disclose their Social Security Number or have a match based on name, birth date, and address so that they can be matched to 831 file) and who applied for SSDI while being surveyed by the SIPP. We also restrict our sample to individuals age 18 to 66 at the time of SSDI application. These restrictions result in a sample of 4,594 SSDI applicants, and 26,136 person-month observations.

Our sample respondents may have multiple disability applications in the years covered by the administrative data. We focus on the first application we observe in the administrative data to be sure we can observe income and its sources in the SIPP before and after application for SSDI benefits. While the vast majority (85.4 percent) of our sample contains complete information on the first application process, some cases are pending within the SIPP and thus we do not observe the entire application period. For these cases, while we are able to obtain the application duration and determination information from the administrative data, we do not have associated time-varying demographics, income amounts or sources, or information related to coping strategies for applications months that are not covered by the SIPP panel. Moreover, this right-censoring is more likely to affect individuals with longer application durations compared to individuals with shorter durations, as well as more recent (2008) panelists. If individuals with different application durations differ systematically in terms of both observable and unobservable characteristics, right-censoring may potentially create biases for our analysis. To address this issue, we run a sensitivity analyses on the subsample for which we observe the entire application period.

Descriptive Statistics. Table 1 presents averages for the socioeconomic characteristics of SSDI applicants measured at the month of application. The average age of applicants is 45, slightly more than half are male, and slightly more than three-quarters are white. Educational attainment is roughly evenly distributed between high school drop-outs, high school graduates, and those who have at least some college. Half of all applicants are married at the time of application. On average, household income of just over \$3,000 per month supports almost three people. A quarter of applicants have worked in the month of application. Almost half of all applicants apply for both SSDI and SSI, suggesting that these applicants do have relatively strong attachment to the labor force - they have worked enough to be insured by SSDI - but remain low-income - their income and assets are low enough that they qualify for SSI benefits. 
There are differences in demographic characteristics of our sample and that of Bound, Burkhauser, and Nichols (2003). Our sample of SSDI applicants is more likely to be female and a high-school drop-out, and less likely to be married, and have larger household size but lower household income. These differences in samples can largely be explained by changes in applicants over time. Table 2 compares applicants of the 1990s to applicants of the 2000s. The starkest difference is the gender composition: 55 percent of applicants were male in the 1990s but only 47 percent are in the 2000s. This is likely due to the shift towards more labor market activity among women, which makes them relatively newly eligible for the SSDI program. The educational background of applicants has also changed significantly, with the proportion of applicants without a high school degree dropping from one-third to one-fifth, likely mirroring overall trends in education during this time period. Applicants in the 2000s are also less likely to be married, and while their monthly earnings and household incomes are similar, personal income is lower among the more recent applicants.

\section{Overview of Coping Strategies}

We examine the following strategies SSDI applicants use to fund consumption while waiting: (1) government transfers, including SNAP, UI, and workers' compensation; (2) earnings of the spouse; (3) changing living arrangement; (4) borrowing from credit cards; (5) liquidation of housing assets. Given the complexity of these programs, we briefly discuss rules and regulations that are relevant for this study and how eligibility for each coping strategy is determined. Table 3 summaries the use of each coping strategy at the time of application. ${ }^{9}$

The Supplemental Nutrition Assistance Program. The SNAP is the largest nutrition program for low-income Americans and a mainstay of the federal safety net. To receive SNAP, households must meet three financial criteria: a gross-income test, a net-income test, and an asset test. A household is automatically or "categorically" eligible for SNAP through the receipt of SSI, Temporary Assistance for Needy Families (TANF), or General Assistance benefits. SSI and SSDI benefits are part of gross household income. The amount of SNAP benefit that a household receives is equal to the maximum benefit level less 30 percent of the household's net income

\footnotetext{
${ }^{9}$ For some of coping strategies, we need information from topic modules of the SIPP. Therefore, the sample size changes due to the merge procedure.
} 
(reflecting the assumption that an average household will spend approximately 30 percent of its net income on food).

We determine SNAP eligibility accounting for gross and net income tests, the dependent, shelter, medical expenditure deductions, and categorical eligibility. But we ignore the asset eligibility test for three reasons. First, while the SIPP has information on assets, it comes from the special topical module of the SIPP, which is only asked infrequently (the maximum is once each year per panel with the timing varying substantially by SIPP panel). While the monthly asset information can be estimated using the linear extrapolation, the method does not reflect potential fluctuations of assets, a potentially large bias given the population we are studying. Second, the existing literature suggests that asset variables in the SIPP suffer from measurement error (Strand, Rupp, and Davies 2009). Finally, the literature also suggests that income limits are much more likely to be binding than asset limits (e.g., Coe and Wu 2013).

Overall, almost half of our sample is estimated to be eligible for SNAP at the time of application. As is typical in needs-based programs, take-up is relatively low at 32 percent (Table 3).

Unemployment Insurance. UI is a federal-state partnership providing short-term cash benefits to individuals who lose their jobs through no fault of their own, i.e. either involuntarily or voluntarily with a good cause (e.g. due to illness). Unemployed workers are eligible for UI benefits if they fulfill all monetary and non-monetary requirements. Monetary entitlement requires sufficiently high wage earnings during the first four of the last five completed calendar quarters before the worker files a claim. Non-monetary eligibility criteria concern both the reason for job separation and ongoing claims. Weekly UI benefit formulas specify a minimum and a maximum benefit amount as well as a percentage within these boundaries. The duration of benefits is either set at a fixed level for all UI recipients (nine states), or depends on the total amount of benefits unemployed workers can receive during their eligibility period.

We determine UI eligibility based on monetary eligibility alone, because we cannot infer the reasons for a job separation from the survey. This leads to a relatively high estimate: 58 percent in our sample are eligible for UI at the time of application. Due to the mismeasurement in eligibility and the small overlap between SSDI applicants and UI claimants (Lindner 2011), we find a low take up rate of under 7 percent. Delaying SSDI applications until UI benefits expire might also account for this low take-up rate (Rutledge 2012). 
Worker's Compensation. Worker's compensation is a state-mandated insurance program that provides compensation to employees who suffer job-related injuries and illnesses. Each state has its own laws and programs. Independent contractors are not entitled to worker's compensation. Since we do not know where an injury occurred, we are not able to determine the eligibility for worker's compensation. Overall, nearly 7 percent receive benefits, which is comparable to the literature (Social Security Administration, 2010).

Changing Living Arrangement. SSDI applicants could cut expenses by changing their living arrangements, such as moving into relatives' house or into lower-costs housing. The only variable that is available from the SIPP on this dimension is whether respondents change addresses. Overall, 4 percent changed their address between the month before and the month of application. This is a much higher mover rate than the average mover rate. ${ }^{10}$

Spousal Insurance. The interaction of couple's labor supply has been widely discussed in the literature (Heckman 1974, for example). Couples can self-insure through intra-family labor market substitution; i.e., if one person cannot work, the other spouse can enter the labor market. This is often referred to as the added-worker effect. We measure this strategy by examining: 1) changes in marital status; 2) employment and changes in employment of the spouse; 3) earnings and changes in earnings of the spouse. At the time of application, over 60 percent of spouses are working, and the average earnings among employed spouses are $\$ 2,775$ per month.

Borrowing from Credit Cards. An SSDI applicant can also borrow from credit cards to fund consumption while their application is pending. Overall, 17 percent of SSDI applicants have an outstanding balance from credit cards in the month of application, which is lower than the 20 percent for the overall SIPP sample of the same age $(t=6.5)$. Among applicants with a credit card balance, the average balance is $\$ 3,451$ and the median is $\$ 1,421$.

Liquidation of Housing Assets. SSDI applicants who own a home could also can partially or fully liquidate housing assets to support the consumption. Unfortunately, only information on home ownership is available from the SIPP; therefore, we will not be able to measure partial liquidation, such as borrowing from home equity line of credit. About 61 percent of the sample

\footnotetext{
${ }^{10}$ The mover rate was between 12 and 30 percent per year, or about 1-2 percent per month, for the last decades (Ihrke and Farber 2012).
} 
own a house 12 months prior to application, and only 59 percent at the time of application are home owners.

\section{The Use of Coping Strategies at Application Onset, and before and after Application}

The average application duration is over 6 months, or approximately 200 days, but wait times are quite skewed to the left, as depicted by Figure 1 . Specifically, the $25^{\text {th }}$ percentile is 60 days, the median wait time is 101 days, and the $75^{\text {th }}$ percentile is 152 days. The right tail is also quite long, with 12 percent of the sample waiting at least one year, and 5 percent of the sample waiting more than two years.

Table 4 presents descriptive statistics at the month of application by actual application duration. SSDI applicants with less than 3 months of wait-time are more likely to be male or whites and less likely to be divorced, while those who wait longer than 6 months are more likely to be single. There are a few characteristics that show a U-shaped pattern - there is a decreasing trend between no wait and up to 12 months of wait-time, but then reversing the trend among those who wait longer than 12 months before their final determination. For example, the average income is $\$ 1,116$ per month for applicants whose case is determined within the first three months of applications. Average income slowly decreases as the wait time increases, to \$846 per month for those waiting between 6-12 months. However, among those whose case takes longer than 12 months to decide, their income is back up to over $\$ 1,000$ per month. This same pattern holds for employment, earnings and income at both the personal and household level, as well as percent married. We also find that joint SSDI/SSI application exhibits an inverse U-shaped pattern: about 46 percent for applications who wait less than 3 months; the fraction peaks at 54 percent for those waiting between 4-6 months, then declines to 41 percent among those wait for more than 12 months.

Much like with demographics, the correlations between using a certain coping strategy at the month of application and the wait time is not monotonic (Table 4). SSDI applicants who wait for longer than 6 months are less likely to take-up UI benefits, but more likely to receive workers’ compensation. While both spousal employment and home ownership show a U-shaped pattern with the waiting duration, the share borrowing from credit cards and changing address exhibit an inverse U-shape. 
Although we cannot detect much of a relationship between the initial use of coping strategies and the overall wait time, it is quite possible that the use of certain coping strategies changes as time since application progresses. We next explore how applicants use coping strategies in the months before and after their SSDI application.

Specifically, we examine changes in household income and coping strategies of our sample across seven distinct periods related to the timing of the SSDI application, ranging from 20 months before application to 20 months after application (Table 5). The first is between 18 and 20 months before application. We use this period to approximate the economic status of SSDI applicants before the onset of disability began to affect various outcomes. The last period is 18-20 months after application. We use this period to approximate the status of applicants after the full application process has been completed. At this point for most applicants, either benefits have begun or respondents have learned that benefits will not be awarded and have had the opportunity to try to return to work.

Figure 2 describes changes in employment, earnings (whether or not the person is working), and total income over time. Not surprisingly, the percent of applicants employed decreases over time - what is more surprising is that the decrease in employment starts early, even at 8-10 months before application, not just at the time of application; this finding is consistent with Lindner (2013) who documents employment transitions of SSDI applicants. Employment also continues to decline over time, but never goes to zero; 16 percent of the applicants are still employed 18-20 months after they apply for the disability program. Earnings decline over time as well; individual earnings declining the most (primarily because of the drop in employment), whereas household earnings and household income drop less severely.

Along with this decrease in earnings and income comes an increase in eligibility for needs-based assistance; the take-up rate of SNAP among the eligible also increases over time (Figure 3). Unemployment insurance has a humped-shape over time, with more eligible people receiving UI benefits between 10 months prior and their application, then decreasing over time as their application is reviewed and possibly UI benefits expire. Worker's compensation shows the opposite pattern, with the number of applicants receiving benefits increasing over time.

While not shown in the figures, we also find that home ownership declines, suggesting SSDI applicants could be using housing assets to support their consumption. In addition, the probability of changing address decreases over time. While applicants may borrow from credit 
cards to fund consumption while waiting, there is no significant correlation between borrowing from other financial resources and waiting time.

\section{Empirical Methods}

The descriptive analysis above illustrates some interesting correlations between the wait time, demographics, and the use of certain coping strategies. However, the pattern may be confounded by the issue of selection, on either observable or unobservable characteristics. To explore whether and extent to which the length of wait time and other factors relate to certain coping strategies, we first estimate equations of the following form:

$$
\text { Strategy }_{i t}=\beta_{0}+\beta_{1} A W_{i}+\beta_{2} X_{i t}+\gamma_{t}+S_{t}+\varepsilon_{i t}
$$

where Strategy $y_{i t}$ measures each of the five coping strategies indicated above, controlling for the actual total wait time $\left(A W_{i}\right)$, and individual characteristics such as age, race, education, gender, marital status, and family structure $\left(X_{i t}\right) .{ }^{11}$ We also control for secular and short-term changes in program participation and family structure by including a set of year indicator variables $\left(\gamma_{t}\right)$. We include a set of state dummies $\left(S_{t}\right)$ because the wait time for a SSDI award varies substantially depending on where the disabled individuals live and, as highlighted in the public assistance program literature, the use of need-based programs varies substantially by region and state.

Using this regression approach, we analyze the relationship between outcomes and the wait time. In the first specification, we analyze Strategy $y_{i t=a}$, measuring the likelihood of using a coping strategy at the time of application as a function of total application duration $\left(A W_{i}\right)$, controlling for individual characteristics. This set of analyses sheds light on how the wait time is correlated with the initial coping strategy selection. Second, we analyze the outcome Strategy for all months of application as a function of total application duration $\left(A W_{i}\right)$. The results of this model represent the association between the application duration and the average use of a certain coping strategy.

These regressions shed light on the association between various coping strategies and applicants’ waiting times, but they cannot address how people change their coping strategies as

\footnotetext{
${ }^{11}$ Because our descriptive statistics suggest that there is a U-shaped relationship between the actual wait time and some coping strategies, in sensitivity tests, we include a squared term of the actual wait time in our model and the results are largely similar.
} 
they face longer waiting times. For instance, research has demonstrated that a lack of information contributes to welfare program nonparticipation among eligibles (Coe 1983, Blaylock and Smallwood 1984, Hill 1990, Daponte et al. 1999, Wu 2009). Those who are eligible but do not take-up SNAP may also not appeal an initial SSDI denial due to the unfamiliarity of the program rules, which results in a shorter waiting time. To understand better how people change their coping strategies over the course of their waiting time, we next regress the use of a coping strategy on time since application, using waiting time fixed effects to control for unobserved heterogeneity between people with a shorter versus longer overall waiting time. Our regression equation is written as follows:

$$
\text { Strategy }_{i t}=\beta_{0}+\beta_{1} A W_{i t}+\beta_{2} A W_{i}+\beta_{3} X_{i t}+\gamma_{t}+S_{t}+\varepsilon_{i t}
$$

where we analyze $S t r a t e g y_{i t}$ as a function of time since application $\left(A W_{i t}\right)$, controlling for total application time $\left(A W_{i}\right)$. By adding total application duration fixed effects to the model, this approach explores the changes in the use of coping strategies since application given the length of the overall application duration.

This type of regression controls for heterogeneity in the use of coping strategies related to the overall waiting time, but it cannot distinguish between applicants reacting to a exogenously longer waiting time (e.g., because of fewer case workers) and applicants using a coping strategy to file an appeal, which increases their chance of being admitted into the program but also their overall waiting time. For instance, applicants with a spouse who can increase his or her work time and thereby contribute more to household income may be more inclined to appeal an initial denial. To address such endogeneity concerns, we employ an instrumental variable approach.

Because the wait time varies substantially by the location of the applicants and his or her disability condition, we use the average wait time by state-year-stage to instrument for the actual waiting time, where stage refers to initial five-stage determination process Individuals in the lower stages have lower wait times, on average. The stages are as follows:

(1) Applicants must not have engaged in substantial gainful activity (SGA) since disability onset, where SGA is defined as earnings above a threshold $(\$ 1,010 / \$ 1690$ per month for the non-blind/blind applicants in 2012);

(2) Whether the health condition is severe;

(3) Whether the condition is included in the list of disabling conditions;

(4) If neither 2 nor 3, whether the person can do their previous work; 
(5) Whether the person can do any other type of work. ${ }^{12}$

The first stage estimates the effect of state-year-stage average wait time on the individual actual waiting time:

$$
A W_{i}=\beta_{0}+\beta_{1} S S W_{s s t}+\beta_{2} X_{i t}+\gamma_{t}+S_{t}+\varepsilon_{i t}
$$

where $S S W_{s s t}$ is average state-year-stage wait time. As before, we include state and year fixedeffects in this regression.

In the second stage, the predicted value of individual waiting time from the first stage is substituted for actual waiting time.

$$
\text { Strategy }_{i t}=\beta_{0}+\beta_{1} \widehat{A W}_{l}+\beta_{2} X_{i t}+\gamma_{t}+S_{t}+\varepsilon_{i t}
$$

where $\widehat{A W}_{l}$ is the predicted waiting time. Because we include year and state fixed effects as well, identification is from within-state variation in the waiting time that does not reflect common changes across all states in a given year, for instance dues to business cycle conditions. The exclusion restriction requires such changes to be uncorrelated with other factors that affect the use of coping strategies. We believe that this assumption is justified because the identifying variation primarily comes from changes in the number of staff reviewing applications and fluctuations in the number of applications from year to year that are not common across all states.

\section{How Is Application Duration Related to the Use of Coping Strategies?}

Table 6 summarizes regression results using an unbalanced sample, which includes both completed and right-censored observations. ${ }^{13}$ Column (1) and (3) presents regression coefficients of linear probability models estimating equation (1) for the two regressions: month of application and all months of application. Column (2) and (4) presents IV results from equations (3) and (4) for month of application and all months of application, respectively. Even if instruments are relevant, they might be weak. In that case, instrumental variable estimates may be inconsistent and imprecisely measured. Therefore, Table 6 also reports the first stage results from estimating equation (3) and the F statistic, which tests whether the coefficient of the

\footnotetext{
12 See http://www.ssa.gov/dibplan/dqualify5.htm (last accessed: 01/09/2013) for a description.

${ }^{13}$ The detailed regression results on each coping strategy using unbalanced sample are summarized in the Appendix. We explore the potential for right censoring biasing our results in robustness tests (Table 7).
} 
instrument is zero. Column (5) report results regression results estimating equation (2) for regression of months since application.

Each row of the table presents different regression results for each coping strategy separately. Because measured eligibility for SNAP and UI may contain error, we also estimate unconditional recipiency of SNAP and UI. Coefficients for binary variables are expressed as percentages. Table 6 presents the results from 65 (13 coping strategies x 5 estimation models) separate regression models.

With few exceptions, the association between using a coping strategy at the time of application and total application duration is largely absent (Table 6, Column 1). The one exception is being married: a one month longer application duration is associated with an almost 0.15 percent higher probability of being married. However, those who are married are not more likely to have a working spouse or higher income through the spouse. To the contrary, the coefficients for spousal employment and spousal earnings are negative and imprecisely measured. While SNAP recipiency is positively related to a longer application duration though not significantly different from zero, other coping strategies such as UI take-up and worker's compensation recipiency are negative, but insignificant and small. The lack of associations between any initial coping strategy and the final wait time suggests that applicants do not differ systematically in their initial use of coping strategies. The third column shows OLS results for all application months. We find that longer wait times are negatively associated with UI and worker’s compensation benefit recipiency, but positively correlated with home ownership probability.

We then present results for the likelihood of using a coping strategy as a function of time since application, controlling for the overall application duration (Table 6, Column 5). We find that being married is positively associated with total application duration at the month of application, but is uncorrelated with the time since application, suggesting that being married is a precondition for people being able to sustain a longer application duration, and, not surprisingly, applicants do not get married in order to sustain their application. The role of a working spouse is further corroborated by the positive and significant coefficient for spousal employment. This suggests an added worker effect: as applicants remain out of the labor market for a longer time, their spouse starts working to balance lost household income. An alternative interpretation of the coefficient could be that individuals with an initially denied application whose spouse finds 
employment decide to prolong their application by filing an appeal. The coefficient implies that a three-month longer time since application is associated with about a one percent higher employment rate of a spouse. We revisit the interpretation of this coefficient when we discuss the instrumental variables estimation results.

The positive association between spousal employment and time since application also implies a positive association between spousal earnings and time since application, but the coefficient is not precisely estimated. We do not find significant differences for spousal earnings conditional on employment, suggesting that newly working spouses have similar earnings than those already working.

Turning to other income sources, one can see that both SNAP recipiency and take-up conditional on eligibility are positively related to a longer time since application. As with spousal employment, these coefficients are consistent with two interpretations. First, applicants increase take-up as the application goes on, or second, initially rejected applicants decide to file an appeal if they can draw from these income sources. Interestingly, for UI take-up and worker's compensation receipt, we observe negative coefficients, likely because people lose eligibility for these programs over time.

The last two significant coefficients concern where applicants live. The negative coefficient for a change in address suggests that applicants hold off relocating while they are in the midst of their SSDI application. However, homeowners - a majority (58 percent) of applicants - do seem more likely to sell their home as their application duration increases. These two findings seem contradictory. One way to reconcile these differences is that homeowners tap into their home equity to fund consumption during the application process, but renters do not move, perhaps because the money saved in monthly rent is not enough to justify the fixed costs of moving.

The IV estimates of the relationship between using a coping strategy at the time of application/all months of application and total application duration are summarized in Column 2 and Column 4 respectively. The first stage results show that the instrument tends to have the expected sign and is statistically significant - that is, average state-year-stage waiting time are positively correlated to individual actual waiting time. For instance, in the regression for spousal employment, a one month increase in average state-year-stage waiting time is predicted to 
increase individual actual waiting time by 3.4 months. The first stage results also show that the instrumental variable is strong with F-statistics over 10 (Staiger and Stock 1997).

The IV results put the findings from the last specification in perspective. First, they corroborate the positive relationship between the wait time and SNAP recipiency and the negative relationship between the wait time and an address change (when all months are considered). Second, IV coefficients for spousal employment are negative and insignificant, in contrast to the positive and significant coefficient for the time since application specification. These results together suggest that the association between spousal employment and the wait time is due to reverse causality: a higher spousal employment leads to a longer wait time because applicants can more easily appeal an initial denial when their spouse works. Such a relationship between the wait time and spousal employment is captured by the OLS regression but not by the IV regression. Third, for UI and worker's compensation, coefficients of the IV regressions are negative as coefficients of the time since application regression, but insignificant. For these coping strategies, a reverse causality explanation in combination with negative effects does not seem plausible, so the lack of significance for the IV coefficients mostly reflect larger standard errors for IV regressions. Demographic characteristics are correlated with the use of a certain coping strategy as one would expect (see Appendix). For example, age is negatively correlated with using need-based programs and changing address, but positively correlated with homeownership and probability of being married. Minority, low-educated, female applicants, and those with children in the household are more likely to use need-based transfers to fund their consumption. Husbands of applicants are more likely to increase their employment as well as earnings during the application process than wives of applicants. College-educated applicants see the largest increase in spousal earnings, which could reflect assortive mating and a positive association in the market wages between spouses or the lower replacement rate SSDI benefits among higher earning households. Further, higher education is associated with more borrowing from credit cards, which likely reveals easier access to this channel of funding consumption after a disability onset.

By estimating these relationships for an unbalanced sample, we allow individuals with potentially very long wait times to influence the results. However, since the wait time is, at least to some extent, endogenous due to the decision to appeal, and applicants with a longer application duration are more likely to have some non-observed application months due to right- 
censoring which may potentially create biases, we test the robustness of our results by estimating these relationships on a balanced panel. This limits our sample to applicants who have a final decision on their application filed during the SIPP panel, and cuts our sample size by 15 percent. Despite these cuts and the endogeneity concern, our findings are largely consistent between samples (see Table 7). Interestingly, the IV coefficient for UI recipiency (using all months of application) is significant for this sample, which seems very plausible: applicants use UI benefits as a coping strategy as long as they qualify for them.

Finally, as our descriptive statistics show that applicants of the 1990s are significantly different from applicants of the 2000s, we also explore an interaction model with the period dummy interacting with the waiting duration. We find that compared to applicants of the1990s, applicants with longer wait-time of the 2000s are increasingly more likely to use SNAP and UI benefits to fund consumptions while waiting for SSDI benefits, and less likely to use worker's compensation, sell the house, or borrow from credit cards.

\section{Conclusion}

Our analysis shows, while the relationship between the wait time and any particular initial or average coping strategies is largely absent, applicants with longer waiting durations are more likely to use SNAP benefits both as an initial and average coping strategy, and less likely to change one's address to cope over the duration of the application. When we focus on the time since application, we find that in addition to an increased probability of using SNAP and a decreased likelihood of changing one's address, there is a negative relationship between the time since application and receipt of UI, worker's compensation, as well as the probability of owning a house, and a positive relationship between the time since application and spousal employment. Our IV results underline that applicants react to an exogenous increase in the waiting time by increasingly turning to SNAP, a means tested income source with relatively small benefits, as more generous income sources such as UI benefits dwindle. For spousal employment, an increase in the waiting time does not appear to increase the likelihood that an applicant's spouse seeks work. Rather, our IV results in combination with our OLS results for time since application suggest that an increase in spousal employment leads to a longer waiting time, presumably because applicants find it easier to appeal an initial denial. 
Our study provides a first and important step to better understanding how the application duration impacts the use of various coping strategies. The findings of the interaction between SSDI and other government programs suggest that a reallocation of funds to decrease SSDI wait may also decrease outlays for the SNAP. 


\section{References:}

Allsup. 2010. “Allsup Analysis Finds 10 States Top List of Worst for Social Security Disability Insurance Backlogs.” Current News Release, April 6.

Autor, David and Mark Duggan. 2010. "Supporting Work: A Proposal for Modernizing the U.S. Disability Insurance System.” Washington, DC: Center for American Progress and the Hamilton Project.

Autor, David, Maestas, Nicole, Mullen, Kathleen J. and Strand, Alexander. 2011. “Does Delay Cause Decay? The Effect of Administrative Decision Time on the Labor Force Participation and Earnings of Disability Applicants.” Working Paper 2011-258. Ann Arbor, MI: Michigan Retirement Research Center Research.

Blaylock, James. R and David M. Smallwood. 1984. "Reasons for Non-Participation in the Food Stamp Program.” Western Journal of Agricultural Economics, 9: 117-26.

Bound, John, Richard V. Burkhauser, and Austin Nichols. 2003. "Tracking the Household Income of SSDI and SSI Applicants.” In Worker Well-Being and Public Policy (Research in Labor Economics, Volume 22), edited by Solomon W. Polachek, 113-158. Emerald Group Publishing Limited.

Coe, Norma and Kalman Rupp. 2013. "Does Access to Health Insurance Influence Work Effort Among Disability Cash Benefit Recipients?” Working Paper 2013-10. Chestnut Hill, MA: Center for Retirement Research at Boston College.

Coe, Norma and April Yanyuan Wu. 2013. "What Impact does Social Security Have on the Use of Public Assistance Programs among the Elderly?” Working Paper

Coe, Richard D. 1983. "Participation in the Food Stamp Program, 1979.” In Five Thousand American Families - Patterns of Economic Progress, edited by Greg J. Duncan and James N. Morgan, 10: 121-177. Ann Arbor, MI: University of Michigan.

Dale, Stacy Berg and James M. Verdier. 2003. "Elimination of Medicare’s Waiting Period for Seriously Disabled Adults: Impact on Coverage and Costs.” Issue Brief 660. New York: The Commonwealth Fund.

Daponte, Beth Osborne, Seth Sanders, and Lowell Taylor. 1999. "Why Do Low-Income Households Not Use Food Stamps? Evidence from an Experiment.” Journal of Human Resources 34(3): 612-628.

French, Eric and Jae Song. 2009. “The Effect of Disability Insurance Receipt on Labor Supply,” Working paper 2009-05, Chicago, IL: Federal Reserve Bank of Chicago.

Gruber, Jonathan and J. D. Kubik. 2002. "Health Insurance Coverage and the Disability Insurance Application Decision.” Working Paper 2002-04. Chestnut Hill, MA: Center for Retirement Research at Boston College. 
Heckman, James. 1974. "Shadow Prices, Market Wages, and Labor Supply,” Econometrica 42(4):679-694.

Hill, Daniel H. 1990. “An Endogenously-Switching Ordered-Response Model of Information, Perceived Eligibility and Participation in SSI.” The Review of Economics and Statistics. 1990; 72, (2):368-371.

Honeycutt, Todd C. 2004. "Program and Benefit Paths to the Social Security Disability Insurance Program” Journal of Vocational Rehabilitation 21: 83-94.

Ihrke, David K. and Carol S. Faber. 2012. “Geographical Mobility: 2005 to 2010” U.S. Census Bureau.

Lindner, Stephan. 2011. "How do Unemployment Insurance Benefits Affect the Decision to Apply for Social Security Disability Insurance?” University of Michigan.

Lindner, Stephan. 2013. "From Working to Applying: Employment Transitions of Applicants for Disability Insurance in the United States." Journal of Social Policy 42(2): 329-348.

Livermore, Gina, David Stapleton, and Henry Claypool. 2009. "Health Insurance and Health Care Access Before and After SSDI Entry.” Commonwealth Fund publication 1255. New York: The Commonwealth Fund.

Rutledge, Matthew. 2012 “The Impact of Unemployment Insurance Extensions on Disability Insurance Application and Allowances Rates” Working Paper 2011-17. Chestnut Hill, MA: Center for Retirement Research at Boston College.

Riley, Gerald F. 2006. "Health Insurance and Access to Care Among Social Security Disability Insurance Beneficiaries During the Medicare Waiting Period.” Inquiry 43(3): 222-30.

Staiger, Douglas and James H. Stock. 1997. "Instrumental Variables Regressions with Weak Instruments.” Econometrica 65(3): 557-586.

Strand, Alexander, Kalman Rupp, and Paul S. Davies. 2009. "Measurement Error in Estimates of the Participation Rate in Means-Tested Programs: The Case of the US Supplemental Security Income Program for the Elderly.” Working Paper.

Stapleton, D., S. Liu, Dawn Phelps, and Sarah Prenovitz. 2010. "Work Activity and Use of Employment Supports Under the Original Ticket to Work Regulations: Longitudinal Statistics for New Social Security Disability Insurance Beneficiaries.” Washington, DC: Mathematica Policy Research.

Social Security Administration. 2010. Annual Statistical Report on the Social Security Disability Insurance Program. Chapter 7. "Beneficiaries Who Have Filed for Workers' Compensation or Public Disability Benefits.” Baltimore, MD. 
Wu, April Yanyuan. 2009. “Why Do So Few Elderly Use Food Stamps?” Working Paper 10.01. Chicago, IL: The Harris School of Public Policy Studies, The University of Chicago. 
Figure 1. The Cumulative Distribution of Waiting Times

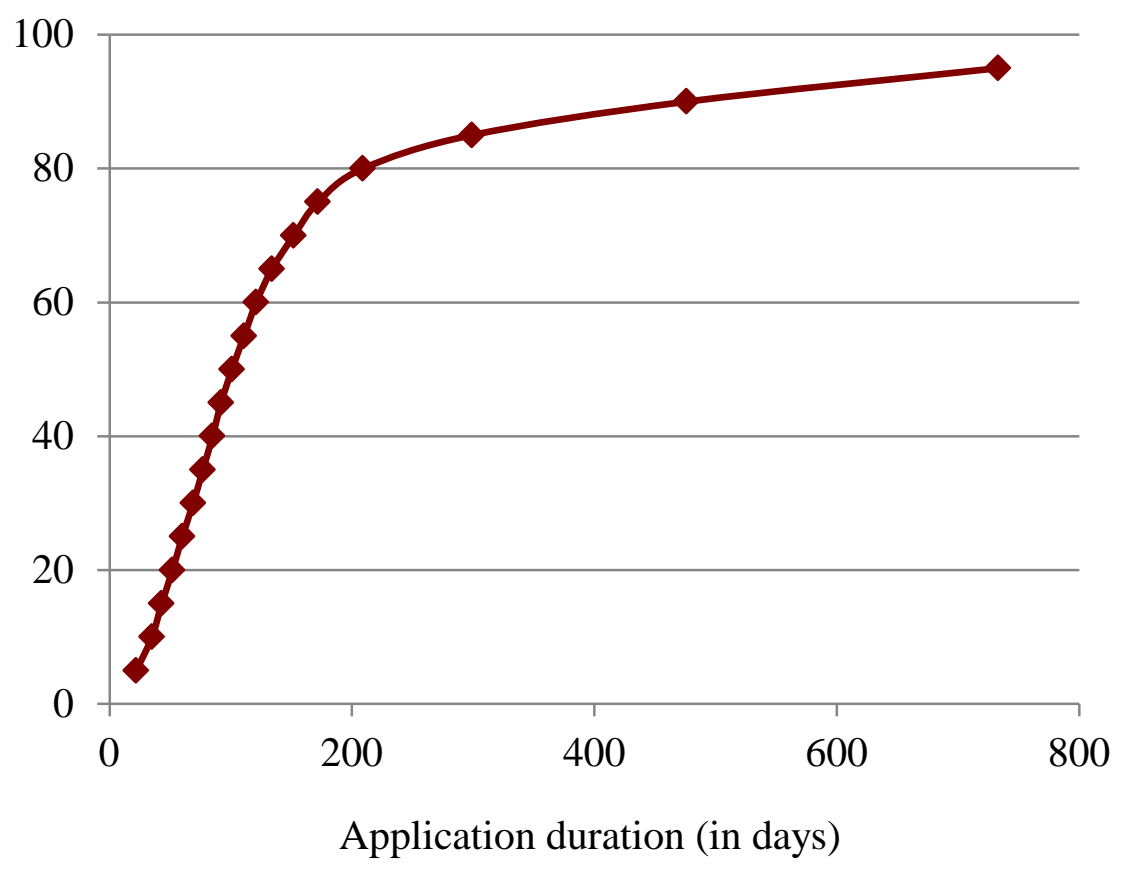

Figure 2. Evolution of Income and Employment Before and After SSDI Application

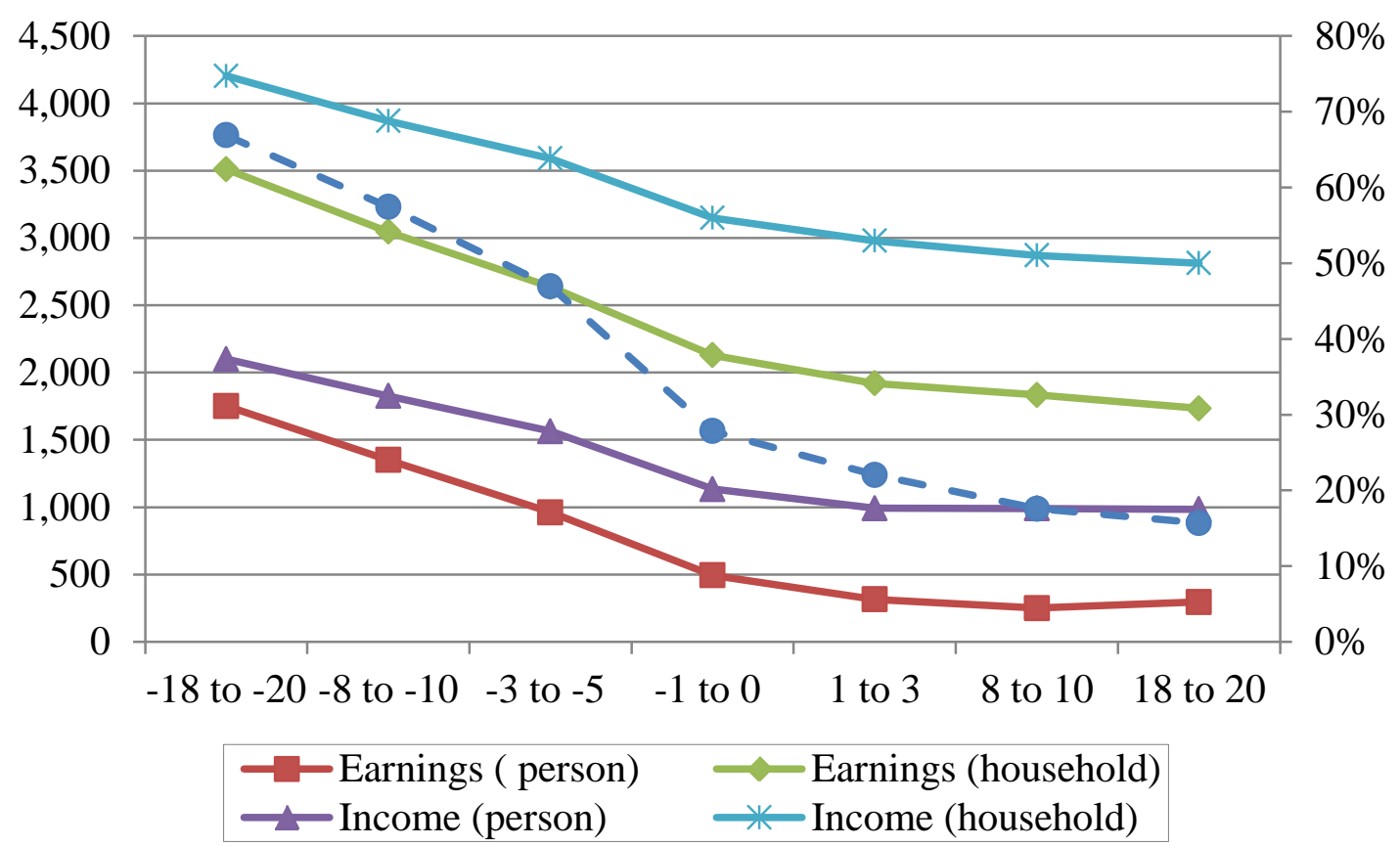


Figure 3. Evolution of Coping Strategies Before and After SSDI Application

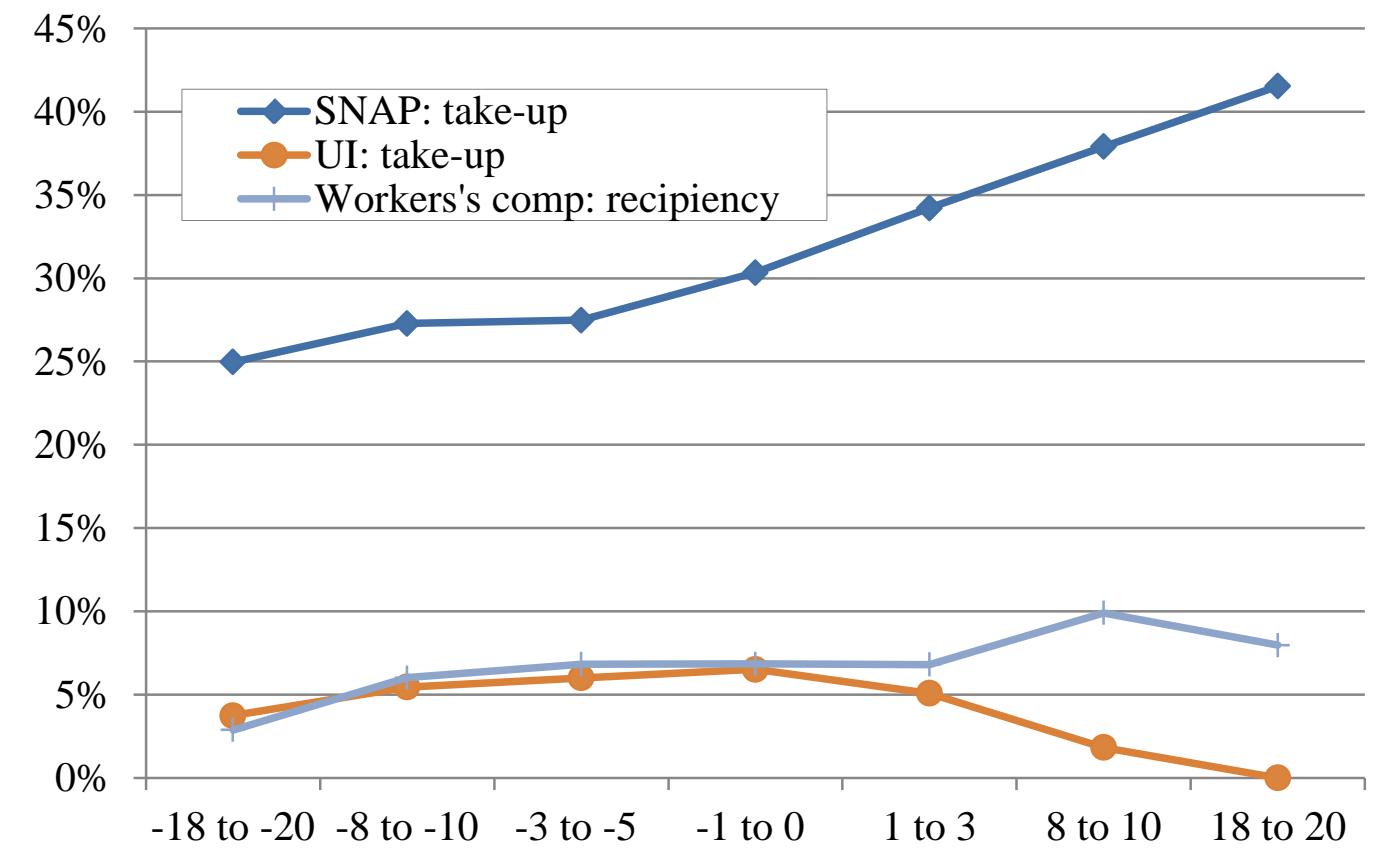


Table 1. Descriptive Statistics of SSDI Applicants, at the Month of Application

\begin{tabular}{|c|c|c|}
\hline & \multicolumn{2}{|c|}{ Month of application } \\
\hline & Mean & Standard deviation \\
\hline Age & 45 & 0.29 \\
\hline Male & 53.8 & 1.2 \\
\hline \multicolumn{3}{|l|}{ Race } \\
\hline White & 78 & 0.92 \\
\hline Black & 19.5 & 0.88 \\
\hline Other & 2.5 & 0.33 \\
\hline \multicolumn{3}{|l|}{ Education } \\
\hline High-school drop-out & 31.6 & 1.02 \\
\hline High-school graduate & 37.3 & 1.06 \\
\hline Some college & 31 & 1.06 \\
\hline \multicolumn{3}{|l|}{ Marital status } \\
\hline Married & 50.4 & 1.11 \\
\hline Divorced & 25.4 & 0.96 \\
\hline Single & 19.2 & 0.96 \\
\hline \multicolumn{3}{|l|}{ Family/household structure } \\
\hline Family size & 2.7 & 0.04 \\
\hline Household size & 2.9 & 0.04 \\
\hline Number of kids in family & 0.7 & 0.02 \\
\hline \multicolumn{3}{|l|}{ Employment } \\
\hline Employed this month & 25.1 & 0.94 \\
\hline \multicolumn{3}{|l|}{ Income } \\
\hline Income (person) & 1,063 & 42.61 \\
\hline Income (household) & 3,086 & 69.47 \\
\hline Earnings (monthly, person) & 415 & 27.6 \\
\hline Earnings (household) & 2,071 & 59.09 \\
\hline \multicolumn{3}{|l|}{ SSDI } \\
\hline Application right-censored & 14.6 & 0.78 \\
\hline Application duration & 6.6 & 0.33 \\
\hline Joint SSDI/SSI application & 47.8 & 1.11 \\
\hline 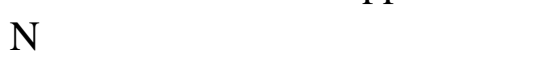 & 4,594 & \\
\hline
\end{tabular}


Table 2. Descriptive Statistics of SSDI Applicants, 1990s vs. 2000s, at the Month of Application

\begin{tabular}{|c|c|c|c|c|}
\hline & \multicolumn{2}{|r|}{$1990 s$} & \multicolumn{2}{|r|}{$2000 s$} \\
\hline & Mean & Standard deviation & Mean & Standard deviation \\
\hline Age & 45.1 & 0.3 & 44.4 & 0.85 \\
\hline Male & 55.2 & 1.28 & 47.2 & 3.02 \\
\hline \multicolumn{5}{|l|}{ Race } \\
\hline White & 78.1 & 1.03 & 77.8 & 2.01 \\
\hline Black & 19.4 & 0.99 & 20.1 & 1.94 \\
\hline Other & 2.5 & 0.37 & 2.1 & 0.6 \\
\hline \multicolumn{5}{|l|}{ Education } \\
\hline High-school drop-out & 33.8 & 1.15 & 21.7 & 2.03 \\
\hline High-school graduate & 37.7 & 1.17 & 35.7 & 2.44 \\
\hline Some college & 28.6 & 1.09 & 42.6 & 2.9 \\
\hline \multicolumn{5}{|l|}{ Marital status } \\
\hline Married & 51 & 1.21 & 47.7 & 2.75 \\
\hline Divorced & 25.4 & 1.07 & 25 & 2.12 \\
\hline Single & 18.5 & 0.97 & 22.5 & 2.95 \\
\hline \multicolumn{5}{|l|}{ Family/household structure } \\
\hline Family size & 2.7 & 0.05 & 2.6 & 0.09 \\
\hline Household size & 2.9 & 0.05 & 2.9 & 0.07 \\
\hline Number of kids in family & 0.7 & 0.03 & 0.7 & 0.05 \\
\hline \multicolumn{5}{|l|}{ Employment } \\
\hline Employed this month & 24.8 & 1.05 & 26.4 & 2.18 \\
\hline \multicolumn{5}{|l|}{ Income } \\
\hline Income (person) & 1,087 & 49.44 & 954 & 70.1 \\
\hline Income (household) & 3,093 & 76.91 & 3,057 & 161.5 \\
\hline Earnings (monthly, person) & 415 & 31.6 & 417 & 51.96 \\
\hline Earnings (household) & 2,051 & 65.29 & 2,164 & 139.84 \\
\hline \multicolumn{5}{|l|}{ SSDI } \\
\hline Application right-censored & 13.6 & 0.83 & 19.5 & 2.19 \\
\hline Application duration & 6.7 & 0.38 & 5.9 & 0.55 \\
\hline Month of first benefit payment & -12.7 & 0.63 & -12.6 & 0.82 \\
\hline Joint SSDI/SSI application & 47.8 & 1.21 & 47.6 & 2.8 \\
\hline $\mathrm{N}$ & 2,058 & & 2,536 & \\
\hline
\end{tabular}


Table 3. The Use of Coping Strategies at the Month of Application

\begin{tabular}{|c|c|c|}
\hline & \multicolumn{2}{|c|}{ Month of Application } \\
\hline & Mean & Standard Deviation \\
\hline \multicolumn{3}{|l|}{ Government transfers } \\
\hline \multicolumn{3}{|l|}{ SNAP } \\
\hline eligibility & 47.8 & 1.11 \\
\hline take-up rate & 31.8 & 1.48 \\
\hline \multicolumn{3}{|l|}{ UI } \\
\hline eligibility & 58.4 & 1.09 \\
\hline take-up rate & 6.7 & 1.05 \\
\hline \multicolumn{3}{|l|}{ Workers' comp } \\
\hline recipiency & 6.8 & 0.54 \\
\hline \multicolumn{3}{|l|}{ Intra-Family Resources } \\
\hline \multicolumn{3}{|l|}{ Spousal Labor Supply } \\
\hline employment & 62.7 & 1.45 \\
\hline earnings & 2,775 & 80.48 \\
\hline \multicolumn{3}{|c|}{ Other Financial Resources } \\
\hline \multicolumn{3}{|c|}{ Borrowing from credit cards } \\
\hline fraction & 17.1 & 0.82 \\
\hline amount & $3,451.1$ & 278.64 \\
\hline Home ownership & 58.8 & 1.11 \\
\hline \multicolumn{3}{|l|}{ Locational Changes } \\
\hline Changed address & 4.1 & 0.41 \\
\hline $\mathrm{N}$ & 4594 & \\
\hline
\end{tabular}


Table 4. Descriptive Statistics of SSDI Applicants, by Application Duration, at the Month of Applicaton

\begin{tabular}{|c|c|c|c|c|c|c|c|c|}
\hline & \multicolumn{2}{|r|}{ 0-3 months } & \multicolumn{2}{|r|}{ 4-6 months } & \multicolumn{2}{|r|}{ 6-12 months } & \multicolumn{2}{|c|}{ Longer than 12 months } \\
\hline & Mean & Standard deviation & Mean & Standard deviation & Mean & Standard deviation & Mean & Standard deviation \\
\hline Age & 44.8 & 0.41 & 45.1 & 0.5 & 45.6 & 0.92 & 44.9 & 0.98 \\
\hline Male & 55.2 & 1.61 & 53 & 2.21 & 50.9 & 3.95 & 52.5 & 4.64 \\
\hline \multicolumn{9}{|l|}{ Race } \\
\hline White & 79.8 & 1.27 & 76.6 & 1.81 & 75.5 & 3.17 & 75.8 & 2.44 \\
\hline Black & 17.5 & 1.21 & 21.2 & 1.76 & 21.3 & 3.01 & 22.4 & 2.38 \\
\hline Other & 2.7 & 0.48 & 2.2 & 0.57 & 3.2 & 1.33 & 1.8 & 0.77 \\
\hline \multicolumn{9}{|l|}{ Education } \\
\hline High-school drop-out & 31.5 & 1.46 & 31.7 & 1.98 & 31.4 & 3.35 & 32.3 & 2.68 \\
\hline High-school graduate & 36.9 & 1.5 & 37.3 & 2.04 & 39.6 & 3.6 & 37.3 & 2.73 \\
\hline Some college & 31.6 & 1.55 & 31 & 1.97 & 29 & 3.55 & 30.4 & 2.53 \\
\hline \multicolumn{9}{|l|}{ Marital status } \\
\hline Married & 50.6 & 1.59 & 46.1 & 2.1 & 48.3 & 3.72 & 58.8 & 2.79 \\
\hline Divorced & 23.5 & 1.32 & 26.9 & 1.94 & 28.5 & 3.32 & 27.2 & 2.52 \\
\hline Single & 21.1 & 1.49 & 21.3 & 1.74 & 16 & 2.63 & 10.7 & 1.79 \\
\hline \multicolumn{9}{|l|}{ Family/household structure } \\
\hline Family size & 2.7 & 0.06 & 2.7 & 0.07 & 2.7 & 0.13 & 2.8 & 0.09 \\
\hline Household size & 2.9 & 0.06 & 2.9 & 0.07 & 2.9 & 0.13 & 2.9 & 0.09 \\
\hline Number of kids in family & 0.7 & 0.03 & 0.7 & 0.04 & 0.6 & 0.07 & 0.8 & 0.06 \\
\hline \multicolumn{9}{|l|}{ Employment } \\
\hline Employed this month & 25.8 & 1.35 & 23.5 & 1.82 & 21.4 & 2.86 & 27.6 & 2.5 \\
\hline \multicolumn{9}{|l|}{ Income } \\
\hline Income (person) & 1,116 & 68.12 & 1,028 & 75.69 & 846 & 89.36 & 1,075 & 91.1 \\
\hline Income (household) & 3,166 & 106.23 & 2,992 & 124.07 & 2,846 & 200.57 & 3,125 & 165.55 \\
\hline Earnings (monthly, person) & 474 & 43.43 & 363 & 48.26 & 284 & 66.66 & 383 & 62.95 \\
\hline Earnings (household) & 2,170 & 89 & 1,954 & 106.6 & 1,908 & 187.94 & 2,030 & 141.45 \\
\hline \multicolumn{9}{|l|}{ SSDI } \\
\hline Application right-censored & 2.9 & 0.58 & 9.3 & 1.25 & 19.9 & 3.35 & 62.7 & 2.75 \\
\hline Application duration & 1.3 & 0.22 & 4.1 & 0.04 & 8.1 & 0.13 & 28.6 & 1.66 \\
\hline Month of first benefit payment & 5.4 & 0.31 & 7.8 & 0.37 & 11 & 0.46 & 29.4 & 1.69 \\
\hline Joint SSDI/SSI application & 46.4 & 1.6 & 53.5 & 2.11 & 49.5 & 3.71 & 41.2 & 2.77 \\
\hline ( & 2,049 & & 1,476 & & 475 & & 594 & \\
\hline
\end{tabular}


Table 5. The Use of Coping Strategies, by Application Duration, at the Month of Application

\begin{tabular}{|c|c|c|c|c|c|c|c|c|}
\hline & \multicolumn{2}{|c|}{$0-3$ months } & \multicolumn{2}{|c|}{ 4-6 months } & \multicolumn{2}{|c|}{ 6-12 months } & \multicolumn{2}{|c|}{$\begin{array}{l}\text { Longer than } 12 \\
\text { months }\end{array}$} \\
\hline \multicolumn{9}{|l|}{ SNAP } \\
\hline eligibility & 47.5 & 1.6 & 48 & 2.12 & 52.6 & 3.73 & 45.3 & 2.8 \\
\hline take-up rate & 29.7 & 2.1 & 35.5 & 2.88 & 31.1 & 4.6 & 33.2 & 3.88 \\
\hline eligibility & 59.7 & 1.54 & 57.2 & 2.12 & 52.8 & 3.69 & 59.5 & 2.79 \\
\hline take-up rate & 7.1 & 1.79 & 8.1 & 1.59 & 6.2 & 2.49 & 3 & 1.19 \\
\hline \multicolumn{9}{|l|}{ Workers' comp } \\
\hline recipiency & 5.7 & 0.69 & 6.9 & 1.08 & 7.8 & 1.95 & 9.6 & 1.65 \\
\hline \multicolumn{9}{|l|}{ Intra-family resources } \\
\hline \multicolumn{9}{|c|}{ Borrowing from credit cards } \\
\hline fraction & 16 & 1.12 & 18.5 & 1.73 & 19.1 & 2.79 & 16.9 & 2.07 \\
\hline amount & $4,278.4$ & 493.4 & $2,685.7$ & 367.0 & 2237.7 & 493.9 & 3021.7 & 588.7 \\
\hline Home ownership & 60 & 1.6 & 57.2 & 2.11 & 51.4 & 3.73 & 62.2 & 2.73 \\
\hline \multicolumn{9}{|l|}{ Locational changes } \\
\hline Changed address & 3.4 & 0.51 & 5.5 & 0.94 & 2.7 & 1.19 & 5 & 1.15 \\
\hline $\mathrm{N}$ & 2049 & & 1476 & & 475 & & 594 & \\
\hline
\end{tabular}


Table 6. Regression Analysis: Unbalanced Sample

\begin{tabular}{|c|c|c|c|c|c|c|c|c|c|}
\hline Coping Strategies & $\begin{array}{c}\text { Column } 1 \\
\text { Application begin } \\
\text { OLS }\end{array}$ & IV & $\begin{array}{c}\text { Column } 2 \\
\text { Application begin } \\
\text { First Stage }\end{array}$ & F-test & $\begin{array}{c}\text { Column } 3 \\
\text { Application months } \\
\text { OLS }\end{array}$ & IV & $\begin{array}{c}\text { Column } 4 \\
\text { Application months } \\
\text { First Stage }\end{array}$ & F-test & $\begin{array}{c}\text { Column } 5 \\
\text { Application duration FE } \\
\text { Time since application } \\
\text { (months) }\end{array}$ \\
\hline Married & $\begin{array}{c}0.151 * \\
(0.057)\end{array}$ & $\begin{array}{r}0.263 \\
(0.464)\end{array}$ & $\begin{array}{l}1.403 \text { *** } \\
(0.202)\end{array}$ & 48.49 & $\begin{array}{r}0.098 \\
(0.060)\end{array}$ & $\begin{array}{r}0.281 \\
(0.334)\end{array}$ & $\begin{array}{l}2.530 \text { *** } \\
0.46530\end{array}$ & 29.55 & $\begin{array}{r}-0.093 \\
(0.117)\end{array}$ \\
\hline Spousal employment & $\begin{array}{c}-0.114 \\
(0.840)\end{array}$ & $\begin{array}{r}-0.313 \\
(0.692)\end{array}$ & $\begin{array}{l}1.740 \text { *** } \\
(0.291)\end{array}$ & 35.83 & $\begin{array}{l}-0.029 \\
(0.082)\end{array}$ & $\begin{array}{c}-0.133 \\
(0.368)\end{array}$ & $\begin{array}{l}3.339 * * * \\
(0.708)\end{array}$ & 22.27 & $\begin{array}{c}0.318 * \\
(0.161)\end{array}$ \\
\hline Spouse earnings: level & $\begin{array}{r}-0.636 \\
(3.645)\end{array}$ & $\begin{array}{r}-3.39929 \\
(35.084)\end{array}$ & $\begin{array}{l}1.749 \text { *** } \\
(0.291)\end{array}$ & 36.18 & $\begin{array}{r}5.840 \\
(5.101)\end{array}$ & $\begin{array}{r}14.8879 \\
(18.097)\end{array}$ & $\begin{array}{l}3.356 \text { *** } \\
(0.723)\end{array}$ & 21.55 & $\begin{array}{r}9.934 \\
(7.709)\end{array}$ \\
\hline SNAP: recipiency & $\begin{array}{r}0.042 \\
(0.058)\end{array}$ & $\begin{array}{c}0.902 * \\
(0.428)\end{array}$ & $\begin{array}{l}1.389 * * * \\
(0.204)\end{array}$ & 46.24 & $\begin{array}{r}0.051 \\
(0.057)\end{array}$ & $\begin{array}{c}0.785 * \\
(0.330)\end{array}$ & $\begin{array}{l}2.498 \text { *** } \\
(0.464)\end{array}$ & 28.98 & $\begin{array}{l}0.422 * * \\
(0.133)\end{array}$ \\
\hline SNAP: recipiency | eligible & $\begin{array}{r}-0.022 \\
(0.101)\end{array}$ & $\begin{array}{r}1.209 \\
(0.654)\end{array}$ & $\begin{array}{l}1.470 \text { *** } \\
(0.289)\end{array}$ & 25.86 & $\begin{array}{r}0.010 \\
(0.103)\end{array}$ & $\begin{array}{r}1.026 \\
(0.537)\end{array}$ & $\begin{array}{l}2.305 \text { *** } \\
(0.664)\end{array}$ & 12.06 & $\begin{array}{c}0.425 * \\
(0.197)\end{array}$ \\
\hline UI: recipiency & $\begin{array}{l}-0.023 \\
(0.021)\end{array}$ & $\begin{array}{r}0.06 \\
(0.343)\end{array}$ & $\begin{array}{l}1.389 \text { *** } \\
(0.204)\end{array}$ & 46.24 & $\begin{array}{l}-0.022 * \\
(0.010)\end{array}$ & $\begin{array}{r}0.13 \\
(0.134)\end{array}$ & $\begin{array}{l}2.498 * * * \\
(0.464)\end{array}$ & 28.98 & $\begin{array}{l}-0.144 * * * \\
(0.043)\end{array}$ \\
\hline Workers's comp: recipiency & $\begin{array}{l}-0.024 \\
(0.024)\end{array}$ & $\begin{array}{r}0.104 \\
(0.211)\end{array}$ & $\begin{array}{l}1.389 \text { *** } \\
(0.204)\end{array}$ & 46.24 & $\begin{array}{l}-0.043 * * \\
(0.015)\end{array}$ & $\begin{array}{r}-0.101 \\
(0.147)\end{array}$ & $\begin{array}{l}2.498 \text { *** } \\
(0.464)\end{array}$ & 28.98 & $\begin{array}{l}-0.176 * * \\
(0.067)\end{array}$ \\
\hline Changed address & $\begin{array}{r}0.055 \\
(0.042)\end{array}$ & $\begin{array}{l}-0.092 \\
(0.244)\end{array}$ & $\begin{array}{l}1.389 \text { *** } \\
(0.204)\end{array}$ & 46.24 & $\begin{array}{r}-0.011 \\
(0.008)\end{array}$ & $\begin{array}{l}-0.109 * \\
(0.047)\end{array}$ & $\begin{array}{l}2.498 * * * \\
(0.464)\end{array}$ & 28.98 & $\begin{array}{l}-0.083 \text { *** } \\
(0.020)\end{array}$ \\
\hline Home ownership & $\begin{array}{l}-0.115 \\
(0.064)\end{array}$ & $\begin{array}{r}-0.85 \\
(0.482)\end{array}$ & $\begin{array}{l}1.389 \text { *** } \\
(0.204)\end{array}$ & 46.24 & $\begin{array}{c}0.152 * \\
(0.067)\end{array}$ & $\begin{array}{l}-0.453 \\
(0.358)\end{array}$ & $\begin{array}{l}2.498 \text { *** } \\
(0.464)\end{array}$ & 28.98 & $\begin{array}{l}-0.337 * \\
-(0.133)\end{array}$ \\
\hline Whether borrowed- credit card loan & $\begin{array}{r}0.016 \\
(0.058) \\
\end{array}$ & $\begin{array}{r}0.308 \\
(0.618) \\
\end{array}$ & $\begin{array}{l}1.389 * * * \\
(0.204)\end{array}$ & 46.24 & $\begin{array}{r}-0.001 \\
(0.044) \\
\end{array}$ & $\begin{array}{r}-0.166 \\
(0.305) \\
\end{array}$ & $\begin{array}{l}2.498 \text { *** } \\
(0.464) \\
\end{array}$ & 28.98 & $\begin{array}{r}0.039 \\
(0.133) \\
\end{array}$ \\
\hline
\end{tabular}


Table 7. Regression Analysis: Balanced Sample

\begin{tabular}{|c|c|c|c|c|c|c|c|c|c|}
\hline Coping Strategies & $\begin{array}{c}\text { Column } 1 \\
\text { Application begin } \\
\text { OLS }\end{array}$ & IV & $\begin{array}{c}\text { Column } 2 \\
\text { Application begin } \\
\text { First Stage }\end{array}$ & F-test & $\begin{array}{c}\text { Column } 3 \\
\text { Application months } \\
\text { OLS }\end{array}$ & IV & $\begin{array}{l}\text { Column } 4 \\
\text { lication months } \\
\text { First Stage }\end{array}$ & F-test & $\begin{array}{c}\text { Column } 5 \\
\text { Application duration FE } \\
\text { Time since application } \\
\text { (months) }\end{array}$ \\
\hline Married & $\begin{array}{l}0.357 \text { ** } \\
(0.116)\end{array}$ & $\begin{array}{r}-0.302 \\
(0.960)\end{array}$ & $\begin{array}{l}0.733 \text { *** } \\
(0.053)\end{array}$ & 191.39 & $\begin{array}{l}0.560 * * * \\
(0.120)\end{array}$ & $\begin{array}{r}0.521 \\
(0.664)\end{array}$ & $\begin{array}{l}1.285 * * * \\
(0.249)\end{array}$ & 26.53 & $\begin{array}{r}-0.077 \\
-(0.099)\end{array}$ \\
\hline Spousal employment & $\begin{array}{r}-0.038 \\
(0.201)\end{array}$ & $\begin{array}{r}-0.144 \\
(1.744)\end{array}$ & $\begin{array}{l}0.851 * * * \\
(0.116)\end{array}$ & 53.75 & $\begin{array}{r}0.224 \\
(0.249)\end{array}$ & $\begin{array}{r}0.172 \\
(1.004)\end{array}$ & $\begin{array}{l}1.639 * * * \\
(0.293)\end{array}$ & 31.21 & $\begin{array}{r}0.130 \\
(0.192)\end{array}$ \\
\hline Spouse earnings: level & $\begin{array}{r}5.974 \\
(9.515)\end{array}$ & $\begin{array}{r}18.535 \\
(78.937)\end{array}$ & $\begin{array}{l}0.836 \text { *** } \\
(0.117)\end{array}$ & 51.27 & $\begin{array}{r}13.678 \\
(13.341)\end{array}$ & $\begin{array}{r}35.948 \\
(50.923)\end{array}$ & $\begin{array}{l}1.606 \text { *** } \\
(0.292)\end{array}$ & 30.19 & $\begin{array}{r}-1.011 \\
(8.240)\end{array}$ \\
\hline SNAP: recipiency & $\begin{array}{l}0.200 * \\
(0.076)\end{array}$ & $\begin{array}{r}1.098 \\
(0.742)\end{array}$ & $\begin{array}{l}0.731 * * * \\
(0.055)\end{array}$ & 179.06 & $\begin{array}{l}0.726 \text { *** } \\
(0.152)\end{array}$ & $\begin{array}{l}1.294 \text { ** } \\
(0.490)\end{array}$ & $\begin{array}{l}1.270 * * * \\
(0.258)\end{array}$ & 24.28 & $\begin{array}{l}0.405 * * \\
(0.132)\end{array}$ \\
\hline SNAP: recipiency | eligible & $\begin{array}{r}0.234 \\
(0.136)\end{array}$ & $\begin{array}{r}1.605 \\
(1.136)\end{array}$ & $\begin{array}{l}0.841 * * * \\
(0.088)\end{array}$ & 91.73 & $\begin{array}{l}0.863 * * * \\
(0.199)\end{array}$ & $\begin{array}{l}1.67 * \\
(0.708)\end{array}$ & $\begin{array}{l}1.203 * * * \\
(0.336)\end{array}$ & 12.8 & $\begin{array}{l}0.444 * \\
(0.255)\end{array}$ \\
\hline UI: recipiency & $\begin{array}{r}-0.019 \\
(0.042)\end{array}$ & $\begin{array}{r}0.158 \\
(0.690)\end{array}$ & $\begin{array}{l}0.731 \text { *** } \\
(0.055)\end{array}$ & 179.06 & $\begin{array}{r}-0.096 \\
-(0.218)\end{array}$ & $\begin{array}{l}-0.131 * * * \\
(0.023)\end{array}$ & $\begin{array}{l}0.212 * * * \\
(0.384)\end{array}$ & 24.28 & $\begin{array}{l}-0.144 * * \\
(0.044)\end{array}$ \\
\hline UI: recipiency | eligible & $\begin{array}{r}0.067 \\
(0.072)\end{array}$ & $\begin{array}{r}-0.18 \\
(1.006)\end{array}$ & $\begin{array}{l}0.705 * * * \\
(0.076)\end{array}$ & 86.23 & $\begin{array}{l}-0.152 * * \\
(0.050)\end{array}$ & $\begin{array}{r}0.139 \\
(0.719)\end{array}$ & $\begin{array}{l}0.979 * * * \\
(0.184)\end{array}$ & 28.45 & $\begin{array}{l}-0.340 * * * \\
(0.100)\end{array}$ \\
\hline Workers's comp: recipiency & $\begin{array}{r}0.040 \\
(0.057)\end{array}$ & $\begin{array}{r}0.363 \\
(0.369)\end{array}$ & $\begin{array}{l}0.731 \text { *** } \\
(0.055)\end{array}$ & 179.06 & $\begin{array}{r}-0.006 \\
(0.070)\end{array}$ & $\begin{array}{r}-0.066 \\
(0.284)\end{array}$ & $\begin{array}{l}1.270 \text { *** } \\
(0.258)\end{array}$ & 24.28 & $\begin{array}{r}-0.102 \\
(0.102)\end{array}$ \\
\hline Changed address & $\begin{array}{r}0.120 \\
(0.062)\end{array}$ & $\begin{array}{r}-0.155 \\
(0.493)\end{array}$ & $\begin{array}{l}0.731 \text { *** } \\
(0.055)\end{array}$ & 179.06 & $\begin{array}{l}-0.030 * \\
(0.013)\end{array}$ & $\begin{array}{r}-0.186 \\
(0.105)\end{array}$ & $\begin{array}{l}1.270 \text { *** } \\
(0.258)\end{array}$ & 24.28 & $\begin{array}{l}-0.160 * * * \\
(0.035)\end{array}$ \\
\hline Home ownership & $\begin{array}{r}-0.166 \\
(0.125)\end{array}$ & $\begin{array}{r}-1.244 \\
(1.100)\end{array}$ & $\begin{array}{l}0.731 \text { *** } \\
(0.055)\end{array}$ & 179.06 & $\begin{array}{r}-0.365 \\
(0.166)\end{array}$ & $\begin{array}{r}-0.343 \\
(0.703)\end{array}$ & $\begin{array}{l}1.270 \text { *** } \\
(0.258)\end{array}$ & 24.28 & $\begin{array}{r}-0.148 \\
(0.111)\end{array}$ \\
\hline Whether borrowed- credit card loan & $\begin{array}{r}-0.013 \\
(0.126) \\
\end{array}$ & $\begin{array}{r}-0.643 \\
(1.225) \\
\end{array}$ & $\begin{array}{l}0.731 \text { *** } \\
(0.055) \\
\end{array}$ & 179.06 & $\begin{array}{r}0.174 \\
(0.190) \\
\end{array}$ & $\begin{array}{r}0.296 \\
(0.735) \\
\end{array}$ & $\begin{array}{l}1.270 * * * \\
(0.007)\end{array}$ & 24.28 & $\begin{array}{r}0.142 \\
(0.139) \\
\end{array}$ \\
\hline
\end{tabular}


Appendix Table 1. Unbalanced Sample

\begin{tabular}{|c|c|c|c|c|c|c|c|c|c|}
\hline \multirow[b]{2}{*}{ OUTCOME VARIABLE } & \multicolumn{9}{|c|}{ Covariates } \\
\hline & $\begin{array}{l}\text { Time since } \\
\text { application }\end{array}$ & & Age & & Male & & Black & & Other \\
\hline \multirow[t]{2}{*}{ Married } & -0.093 & & 0.714 & $* * *$ & 9.354 & $* * *$ & -19.975 & & -1.730 \\
\hline & $(0.117)$ & & $(0.089)$ & & $(1.674)$ & & $(2.268)$ & & (3.530) \\
\hline \multirow[t]{2}{*}{ Spousal employment } & 0.318 & $*$ & -0.292 & $*$ & -8.229 & $* * *$ & -2.164 & & -4.516 \\
\hline & $(0.161)$ & & $(0.147)$ & & (2.363) & & (3.560) & & $(4.986)$ \\
\hline \multirow[t]{2}{*}{ Spouse earnings: level } & 9.934 & & 2.793 & & -873.104 & $* * *$ & -150.631 & & 305.449 \\
\hline & (7.709) & & $(6.664)$ & & (118.913) & & (173.658) & & $(427.277)$ \\
\hline \multirow[t]{2}{*}{ SNAP: recipiency } & 0.422 & $*$ & -0.279 & $* * *$ & -6.015 & $* * *$ & 8.677 & $* * *$ & 3.896 \\
\hline & $(0.133)$ & & $(0.074)$ & & (1.395) & & $(1.931)$ & & (3.207) \\
\hline \multirow[t]{2}{*}{ SNAP: recipiency | eligible } & 0.425 & $*$ & -0.406 & $* * *$ & -11.482 & $* * *$ & 11.410 & $* * *$ & 7.603 \\
\hline & $(0.197)$ & & $(0.112)$ & & $(2.164)$ & & $(2.640)$ & & $(4.894)$ \\
\hline \multirow[t]{2}{*}{ UI: recipiency } & -0.144 & $* * *$ & -0.027 & & 0.920 & & -0.122 & & 0.175 \\
\hline & $(0.043)$ & & $(0.032)$ & & $(0.563)$ & & $(0.700)$ & & (1.347) \\
\hline \multirow[t]{2}{*}{ UI: recipiency | eligible } & -0.291 & $*$ & -0.101 & $*$ & 1.566 & & -1.041 & & -1.164 \\
\hline & $(0.155)$ & & $(0.051)$ & & $(0.930)$ & & $(1.061)$ & & (2.275) \\
\hline \multirow[t]{2}{*}{ Workers's comp: recipiency } & -0.176 & $* *$ & -0.062 & & 1.730 & * & -0.871 & & 2.427 \\
\hline & $(0.067)$ & & $(0.042)$ & & $(0.868)$ & & $(0.956)$ & & (2.249) \\
\hline \multirow[t]{2}{*}{ Changed address } & -0.830 & $* * *$ & -0.066 & $* * *$ & 0.219 & & -0.048 & & -0.020 \\
\hline & $(0.020)$ & & $(0.014)$ & & $(0.217)$ & & $(0.286)$ & & $(0.527)$ \\
\hline \multirow[t]{2}{*}{ Home ownership } & -0.337 & $*$ & 0.781 & $* * *$ & 0.116 & & -11.948 & $* * *$ & -2.810 \\
\hline & $(0.133)$ & & $(0.090)$ & & $(1.767)$ & & $(2.341)$ & & (4.108) \\
\hline \multirow[t]{2}{*}{ Whether borrowed- credit card loan } & 0.039 & & 0.310 & & -6.991 & $* * *$ & -5.547 & $* *$ & -0.159 \\
\hline & $(0.133)$ & & $(0.083)$ & & $(1.452)$ & & $(1.885)$ & & (3.589) \\
\hline
\end{tabular}


Appendix Table 1. Unbalanced Sample (cont'd)

\begin{tabular}{|c|c|c|c|c|c|c|c|}
\hline \multirow[b]{2}{*}{ OUTCOME VARIABLE } & \multicolumn{7}{|c|}{ Covariates } \\
\hline & $\begin{array}{c}\text { High- } \\
\text { school } \\
\text { graduate }\end{array}$ & $\begin{array}{l}\text { Some } \\
\text { college }\end{array}$ & $\begin{array}{l}\text { Family } \\
\text { size }\end{array}$ & $\begin{array}{l}\text { Number of } \\
\text { kids in } \\
\text { family }\end{array}$ & Windowed & $\begin{array}{l}\text { Divorced/ } \\
\text { separated }\end{array}$ & Single \\
\hline & $(2.283)$ & $(2.362)$ & $(0.009)$ & $(0.013)$ & & & \\
\hline \multirow[t]{2}{*}{ Spousal employment } & $7.335 *$ & $12.569 * * *$ & -0.021 & 0.015 & & & \\
\hline & $(3.352)$ & $(3.409)$ & $(0.014)$ & $(0.019)$ & & & \\
\hline Spouse earnings: level & $(122.496)$ & (139.227) & $(63.503)$ & $(83.587)$ & & & \\
\hline \multirow[t]{2}{*}{ SNAP: recipiency } & $-6.680 * * *$ & $-10.901 * * *$ & $-0.065 * * *$ & $0.139 * * *$ & $14.413 * * *$ & $22.667 * * *$ & 18.785 \\
\hline & $(1.846)$ & $(1.823)$ & $(0.007)$ & $(0.010)$ & $(4.005)$ & $(1.876)$ & (2.246) \\
\hline \multirow[t]{2}{*}{ SNAP: recipiency | eligible } & $-10.301 * * *$ & $-12.302 * * *$ & $-0.082 * * *$ & $0.150 * * *$ & 9.029 & $20.871 * * *$ & 15.801 \\
\hline & $(2.715)$ & $(2.731)$ & $(0.013)$ & $(0.016)$ & (5.013) & $(2.687)$ & (3.178) \\
\hline UI: recipiency & -0.387 & 0.113 & $-0.007 *$ & 0.004 & -2.056 & 0.648 & -0.833 \\
\hline \multirow[t]{2}{*}{ Workers's comp: recipiency } & -1.156 & -1.085 & -0.005 & 0.004 & -2.022 & $-2.775 * *$ & -3.905 \\
\hline & $(1.335)$ & $(1.227)$ & $(0.005)$ & $(0.006)$ & $(1.645)$ & $(1.001)$ & (1.074) \\
\hline \multirow[t]{2}{*}{ Changed address } & -0.149 & -0.297 & $-0.004 * *$ & $0.006 * *$ & 0.439 & $0.914 * *$ & 0.193 \\
\hline & $(0.293)$ & $(0.290)$ & $(0.001)$ & $(0.002)$ & $(0.577)$ & $(0.286)$ & $(0.361)$ \\
\hline \multirow[t]{2}{*}{ Home ownership } & $12.819 * * *$ & $16.983 * * *$ & $0.110 * * *$ & $-0.145 * * *$ & -5.579 & $-15.870 * * *$ & -9.766 \\
\hline & $(2.355)$ & $(2.367)$ & $(0.010)$ & $(0.013)$ & $(4.504)$ & $(2.308)$ & $(2.787)$ \\
\hline \multirow[t]{2}{*}{ Whether borrowed- credit card loan } & $4.082 *$ & $11.777 * * *$ & -0.015 & 0.007 & $15.711 * * *$ & $13.286 * * *$ & 8.381 \\
\hline & $(1.790)$ & $(1.860)$ & $(0.008)$ & $(0.012)$ & $(3.990)$ & $(1.906)$ & (2.325) \\
\hline
\end{tabular}


Appendix Table 2. Balanced Sample

\begin{tabular}{|c|c|c|c|c|c|c|c|c|c|c|}
\hline \multirow[b]{2}{*}{ OUTCOME VARIABLE } & \multicolumn{10}{|c|}{ Covariates } \\
\hline & $\begin{array}{l}\text { Time since } \\
\text { application }\end{array}$ & & Age & & Male & & Black & & Other & \\
\hline \multirow[t]{2}{*}{ Married } & -0.077 & & 0.713 & $* * *$ & 8.388 & $* * *$ & -21.793 & $* * *$ & -4.049 & \\
\hline & $(0.099)$ & & $(0.086)$ & & (1.678) & & $(2.234)$ & & (3.785) & \\
\hline \multirow[t]{2}{*}{ Spousal employment } & 0.130 & & -0.283 & & -8.166 & $* *$ & -4.806 & & -2.910 & \\
\hline & $(0.192)$ & & $(0.154)$ & & $(2.575)$ & & $(4.001)$ & & (5.097) & \\
\hline \multirow[t]{2}{*}{ Spouse earnings: level } & -1.011 & & 5.985 & & -949.320 & $* * *$ & -311.015 & & 110.732 & \\
\hline & $(8.240)$ & & $(6.871)$ & & (127.221) & & (197.666) & & (432.021) & \\
\hline \multirow[t]{2}{*}{ SNAP: recipiency } & 0.405 & $* *$ & -0.252 & $* *$ & -6.337 & $* * *$ & 8.829 & $* * *$ & 6.678 & \\
\hline & $(0.132)$ & & $(0.078)$ & & (1.437) & & (1.967) & & (3.559) & \\
\hline \multirow[t]{2}{*}{ SNAP: recipiency | eligible } & 0.444 & $*$ & -0.369 & $* *$ & -12.205 & $* * *$ & 12.106 & $* * *$ & 12.275 & $*$ \\
\hline & $(0.225)$ & & $(0.118)$ & & $(2.303)$ & & $(2.709)$ & & $(5.297)$ & \\
\hline \multirow[t]{2}{*}{ UI: recipiency } & -0.144 & $* *$ & -0.037 & & 1.219 & & -0.455 & & 0.165 & \\
\hline & $(0.044)$ & & $(0.036)$ & & $(0.656)$ & & $(0.843)$ & & $(1.550)$ & \\
\hline \multirow[t]{2}{*}{ UI: recipiency | eligible } & -0.340 & $* * *$ & -0.123 & $*$ & 1.804 & & -2.006 & & -1.136 & \\
\hline & $(0.100)$ & & $(0.058)$ & & $(1.052)$ & & $(1.218)$ & & $(2.658)$ & \\
\hline \multirow[t]{2}{*}{ Workers's comp: recipiency } & -0.102 & & -0.086 & $*$ & 2.238 & $* *$ & -1.034 & & 3.756 & \\
\hline & $(0.102)$ & & $(0.044)$ & & $(0.861)$ & & $(0.941)$ & & $(2.521)$ & \\
\hline \multirow[t]{2}{*}{ Changed address } & -0.160 & $* * *$ & -0.063 & $* * *$ & 0.247 & & -0.057 & & -0.031 & \\
\hline & $(0.035)$ & & $(0.015)$ & & $(0.238)$ & & $(0.337)$ & & $(0.577)$ & \\
\hline \multirow[t]{2}{*}{ Home ownership } & -0.148 & & 0.786 & $* * *$ & 0.735 & & -14.684 & $* * *$ & -3.289 & \\
\hline & $(0.111)$ & & $(0.096)$ & & $(1.776)$ & & $(2.301)$ & & $(4.404)$ & \\
\hline \multirow[t]{2}{*}{ Whether borrowed- credit card loan } & 0.142 & & 0.035 & & -6.517 & $* * *$ & -6.115 & $* *$ & -1.569 & \\
\hline & $(0.139)$ & & $(0.085)$ & & (1.546) & & (1.938) & & $(3.576)$ & \\
\hline
\end{tabular}


Appendix Table 2. Balanced Sample (cont'd)

\begin{tabular}{|c|c|c|c|c|c|c|c|c|}
\hline \multirow[b]{2}{*}{ OUTCOME VARIABLE } & \multicolumn{8}{|c|}{ Covariates } \\
\hline & & $\begin{array}{c}\text { High- } \\
\text { school } \\
\text { graduate }\end{array}$ & Some college & Family size & $\begin{array}{l}\text { Number of } \\
\text { kids in } \\
\text { family }\end{array}$ & Windowed & $\begin{array}{l}\text { Divorced/ } \\
\text { separated }\end{array}$ & Single \\
\hline Married & & $(2.211)$ & $(2.255)$ & $(0.010)$ & $(0.014)$ & & & \\
\hline \multirow[t]{2}{*}{ Spousal employment } & & 5.964 & $10.150 * *$ & -0.021 & 0.012 & & & \\
\hline & & $(3.512)$ & $(3.563)$ & $(0.015)$ & $(0.020)$ & & & \\
\hline Spouse earnings: level & & $(132.801)$ & $(149.457)$ & $(67.514)$ & $(84.172)$ & & & \\
\hline \multirow[t]{2}{*}{ SNAP: recipiency } & & $-7.491 * * *$ & $* \quad-11.598 * * *$ & $* \quad-0.063 * * *$ & $0.135 * * *$ & $11.457 * *$ & $23.466 * * *$ & 18.742 \\
\hline & & $(2.019)$ & $(2.017)$ & $(0.008)$ & $(0.011)$ & $(3.752)$ & $(2.006)$ & (2.259) \\
\hline \multirow[t]{2}{*}{ SNAP: recipiency | eligible } & $*$ & $-12.177 * * *$ & $-13.704 * * *$ & $-0.078 * * *$ & $0.147 * * *$ & 7.224 & $20.726 * * *$ & 14.417 \\
\hline & & $(2.949)$ & $(2.961)$ & $(0.013)$ & $(0.017)$ & $(5.224)$ & $(2.884)$ & (3.377) \\
\hline UI: recipiency & & -0.214 & 0.259 & $-0.008 *$ & 0.006 & -1.999 & 0.282 & -1.293 \\
\hline \multirow[t]{2}{*}{ Workers's comp: recipiency } & & -1.177 & -1.020 & 0.001 & -0.004 & -0.478 & -1.841 & -3.364 \\
\hline & & $(1.440)$ & (1.324) & $(0.005)$ & $(0.006)$ & $(1.814)$ & $(0.972)$ & (1.083) \\
\hline \multirow[t]{2}{*}{ Changed address } & & -0.135 & -0.320 & $-0.003 *$ & $0.004 *$ & 0.281 & $1.078 * *$ & 0.052 \\
\hline & & $(0.331)$ & $(0.321)$ & $(0.001)$ & $(0.002)$ & $(0.645)$ & $(0.330)$ & $(0.399)$ \\
\hline \multirow[t]{2}{*}{ Home ownership } & & $10.957 * * *$ & $14.724 * * *$ & $0.103 * * *$ & $-0.144 * * *$ & 3.400 & $-17.600 * * *$ & -9.138 \\
\hline & & $(2.432)$ & $(2.422)$ & $(0.010)$ & $(0.014)$ & $(4.382)$ & (2.329) & (2.799) \\
\hline \multirow[t]{2}{*}{ Whether borrowed- credit card loan } & & 1.202 & $9.583 * * *$ & -0.010 & 0.004 & $18.286 * * *$ & $14.046 * * *$ & 7.874 \\
\hline & & $(1.941)$ & $(1.988)$ & $(0.008)$ & $(0.012)$ & $(4.170)$ & $(2.007)$ & (2.313) \\
\hline
\end{tabular}




\section{RECENT WORKING PAPERS FROM THE CENTER FOR RETIREMENT RESEARCH AT BOSTON COLLEGE}

The Impact of Population Aging and Delayed Retirement on Workforce Productivity Gary Burtless, May 2013

Does Access to Health Insurance Influence Work Effort Among Disability Cash Benefit Recipients?

Norma B. Coe and Kalman Rupp, April 2013

How Will Older Workers Who Lose Their Jobs During the Great Recession Fare in the Long-Run?

Matthew S. Rutledge, Natalia Orlova, and Anthony Webb, March 2013

Can Long-Term Care Insurance Partnership Programs Increase Coverage and Reduce Medicaid Costs?

Wei Sun and Anthony Webb, March 2013

SSI for Disabled Immigrants: Why Do Ethnic Networks Matter?

Delia Furtado and Nikolaos Theodoropoulos, February 2013

The Use of VA Disability Benefits and Social Security Disability Insurance Among Veterans

Janet M. Wilmoth, Andrew S. London, and Colleen M. Heflin, February 2013

How Does the Composition of Disability Insurance Applicants Change Across Business Cycles?

Norma B. Coe and Matthew S. Rutledge, February 2013

The Economic Implications of the Department of Labor's 2010 Proposals for BrokerDealers

Alicia H. Munnell, Anthony Webb, and Francis M. Vitagliano, January 2013

What Is the Long-Term Impact of Zebley on Adult and Child Outcomes?

Norma B. Coe and Matthew S. Rutledge, January 2013

Sticky Ages: Why Is Age 65 Still a Retirement Peak?

Norma B. Coe, Mashfiqur R. Khan, and Matthew S. Rutledge, January 2013

Rethinking Optimal Wealth Accumulation and Decumulation Strategies in the Wake of the Financial Crisis

Richard W. Kopcke, Anthony Webb, and Josh Hurwitz, January 2013

All working papers are available on the Center for Retirement Research website (http://crr.bc.edu) and can be requested by e-mail (crr@bc.edu) or phone (617-552-1762). 